\title{
Analisis kemampuan komunikasi matematis mahasiswa dalam pembelajaran relasi rekurensi
}

\author{
Andhika Ayu Wulandari ${ }^{1}$, , Erika Laras Astutiningtyas ${ }^{2}$ \\ 1,2Program Studi Pendidikan Matematika, Universitas Veteran Bangun Nusantara Sukoharjo. Jalan \\ Letjend S. Humardani No. 1, Kampus Jombor Sukoharjo, Indonesia. \\ E-mail: ${ }^{\text {dhikamath.univet@gmail.com }}$ * \\ * Korespondensi Penulis.
}

Article received : 9 Maret 2020, article revised : 6 Mei 2020, article published: 10 Mei 2020

\begin{abstract}
Abstrak: Komunikasi matematis pada dasarnya adalah proses penyampaian gagasan matematika. Dengan menganalisis kemampuan komunikasi matematis, dosen dapat mengukur pemahaman mahasiswa dalam merepresentasikan konsep dan solusi untuk menyelesaikan permasalahan. Oleh karena itu, dalam pembelajaran relasi rekurensi sebagai salah satu materi perkuliahan Matematika Diskrit yang membutuhkan pemahaman konsep mahasiswa untuk menyelesaikan permasalahan rekurensi, dosen perlu mengetahui kemampuan komunikasi matematis mahasiswa. Penelitian ini merupakan penelitian deskriptif kualitatif dengan tujuan untuk mendeskripsikan kemampuan komunikasi matematis mahasiswa semester VI Pendidikan Matematika Universitas Veteran Bangun Nusantara Sukoharjo dalam mengerjakan tes pemahaman relasi rekurensi. Instrumen yang digunakan adalah tes tertulis dan lisan berupa pedoman wawancara yang telah dinilai layak oleh validator. Penelitian yang dilakukan dengan grounded theory menyimpulkan bahwa mahasiswa dengan kemampuan komunikasi matematis tinggi mampu menggambarkan situasi masalah, menyatakan solusi menggunakan tabel dan penyajian secara aljabar, menginterpretasikan gagasan dalam bentuk tulisan, menggunakan bahasa matematika dan simbol secara tepat dan merepresentasikan konsep matematika dan solusinya. Sedangkan mahasiswa dengan kemampuan komunikasi matematis sedang dan rendah tidak mampu dalam menginterpretasikan gagasan dalam bentuk tulisan. Kemampuan untuk menyatakan solusi masalah menggunakan tabel/bagan juga tidak dimiliki mahasiswa dengan kemampuan komunikasi matematis rendah. Persentase capaian tertinggi kemampuan komunikasi matematis ada pada indikator menggambarkan situasi masalah sebesar $86,54 \%$. Sedangkan persentase capaian terendah ada pada indikator menginterpretasikan gagasan dalam bentuk tulisan sebesar 48,07\%.
\end{abstract}

Kata Kunci: Kemampuan Komunikasi; Komunikasi Matematis; Relasi Rekurensi

\section{Analysis of student's mathematical communication skills on recurrence relation learning}

Abstract: Mathematical communication is basically the process of delivering mathematical ideas. By analyzing mathematical communication skills, lecturers can measure students' understanding in representing concepts and solutions to solve problems. Therefore, in learning recurrence relations as one of the Discrete Mathematics lectures that requires understanding of student concepts to solve recurrence problems, lecturers need to know the students' mathematical communication skills. This research is a qualitative descriptive study with the aim to describe the mathematical communication skills of the sixth semester students of Mathematics Education at the Veteran Bangun Nusantara Sukoharjo University of in working on the understanding test of recurrence relation. The instrument used was a written and oral test in the form of an interview guide that was judged to be eligible by validators. Research conducted with grounded theory concludes that students with high mathematical communication skills are able to describe problem situations, state solutions using tables and algebraic representations, interpret ideas in written form, use mathematical language and symbols appropriately and represent mathematical concepts and solutions. While students with moderate and low mathematical communication skills are not able to interpret ideas in written form. The ability to express problem solutions using tables/charts also lacks students with low mathematical communication skills. The highest percentage of

CITATION FORMATS: Wulandari, A. A., \& Astutiningtyas, E. L. (2020). Analisis kemampuan komunikasi matematis mahasiswa dalam pembelajaran relasi rekurensi. Jurnal Math Educator Nusantara: Wahana Publikasi Karya Tulis Ilmiah Di Bidang Pendidikan Matematika,6(1), 54-64. 
mathematical communication skills is in the indicator describing the problem situation of $86.54 \%$. While the lowest achievement percentage is in the indicator of interpreting ideas in written form by $48.07 \%$.

Keywords: Communication Skills; Mathematical Communication; Recurrence Relation

\section{PENDAHULUAN}

Proses belajar mengajar pada dasarnya adalah proses komunikasi (Murdiyanto \& Mahatama, 2014; Sür \& Delice, 2016; Jatmiko \& Yohanie, 2018) . Hal yang sama juga dinyatakan oleh (Khan et al., 2017) bahwa komunikasi merupakan proses dimana seseorang berbagi pengetahuannya dengan orang lain. Proses komunikasi dinyatakan dalam tiga sudut pandang oleh (Majid, 2012) yaitu: (1) komunikasi pada dasarnya merupakan suatu proses penyampaian informasi, (2) komunikasi adalah proses penyampaian gagasan/ide dari seseorang kepada orang lain, (3) komunikasi diartikan sebagai proses representasi gagasan atau ide yang disampaikan.

Komunikasi dalam hubungannya dengan matematika dipertegas oleh Kusumah dalam (Jazuli, 2009) yang menyatakan bahwa komunikasi merupakan bagian yang sangat penting dalam pembelajaran matematika. Lebih lanjut Kusumah (2008) menyatakan bahwa melalui komunikasi, ide matematika dapat dieksploitasi dalam berbagai perspektif, cara berfikir dapat dipertajam, pertumbuhan pemahaman dapat diukur, pemikiran dapat dikonsolidasikan dan diorganisir, pengetahuan matematika dan pengembangan masalah dapat ditingkatkan, dan komunikasi matematika dapat dibentuk.

Pentingnya komunikasi dalam pembelajaran matematika juga tertuang dalam Peraturan Menteri Pendidikan Nasional No. 22 Tahun 2006 tentang Standar Isi. Peraturan tersebut menyatakan bahwa salah satu tujuan pembelajaran matematika adalah agar peserta didik memiliki kemampuan mengkomunikasikan gagasan dengan simbol, tabel, diagram, atau media lain untuk memperjelas keadaan atau masalah. Hal ini sejalan dengan tujuan umum pembelajaran matematika yang dirumuskan NCTM/National Council of Teachers of Mathematics (2000). NCTM mengungkapkan bahwa dalam pembelajaran matematika, peserta didik dituntut untuk memiliki kemampuan berpikir dan bernalar tentang matematika dan mengungkapkan hasil pemikiran mereka secara lisan maupun tulisan. Lebih lanjut, (NCTM (National Council of Teachers of Mathematics), 2000; Wood, 2012) menyebut kemampuan untuk menyampaikan gagasan matematika tersebut dengan kemampuan komunikasi matematis (mathematical communication).

NCTM dalam (Walle, 2006) mengungkapkan bahwa tanpa komunikasi dalam matematika, pendidik akan memiliki sedikit keterangan, data, dan fakta tentang pemahaman peserta didik dalam melakukan proses dan aplikasi matematika. Berdasarkan hal tersebut, (Purnama \& Afriansyah, 2016) menyimpulkan bahwa komunikasi dalam matematika dapat membantu pendidik memahami kemampuan yang dimiliki peserta didik dalam menginterpretasikan dan mengekspresikan pemahamannya tentang konsep dan proses matematika yang telah dipelajari. Kesalahan konsep dan tingkat pemahaman yang dimiliki mahasiswa terhadap materi yang diajarkan dapat dijadikan sebagai bahan acuan menentukan strategi pembelajaran yang tepat agar memperoleh hasil belajar yang lebih 
optimal. Oleh karena itu, sangat penting bagi pendidik (dalam hal ini dosen) untuk mengetahui tingkat kemampuan komunikasi matematis mahasiswa.

Baroody dalam (Husna, R., Saragih, S., 2013) mengemukakan alasan mengapa komunikasi matematis sangat penting dalam pembelajaran matematika, yaitu: (1) mathematics as language, artinya bahwa matematika tidak hanya sebagai alat untuk menemukan pola, menyelesaikan masalah atau mengambil kesimpulan. Akan tetapi, matematika juga sebagai alat untuk mengkomunikasikan gagasan secara jelas dan tepat; (2) mathematics learnings social activity, artinya bahwa matematika sebagai aktivitas sosial dalam pembelajaran, wahana interaksi antar peserta didik, dan juga komunikasi antar guru dan siswa. Demikian halnya dalam pembelajaran relasi rekurensi sebagai salah satu materi dalam perkuliahan Matematika Diskrit. Komunikasi matematis menjadi salah satu hal yang penting untuk dianalisis. Dengan mengetahui kemampuan komunikasi matematis mahasiswa dalam pembelajaran relasi rekurensi, dosen dapat mengukur tingkat pemahaman mahasiswa dalam merepresentasikan konsep dan solusi untuk menyelesaikan suatu permasalahan rekurensi. Selain itu, dosen dapat mengetahui kemampuan mahasiswa dalam menuliskan simbol dan notasi relasi rekurensi karena berkenaan dengan konsep pada materi tersebut. Oleh karena itu, perlu dilakukan analisis terhadap kemampuan komunikasi matematis mahasiswa dalam pembelajaran relasi rekurensi.

Ada lima aspek komunikasi dalam mengukur kemampuan komunikasi matematis menurut Baroody dalam (Qohar, 2011) yaitu representasi, mendengar, membaca, diskusi dan menulis. Secara umum, kemampuan komunikasi matematis dapat dibedakan menjadi kemampuan komunikasi matematis lisan dan kemampuan komunikasi matematis tertulis, (Disasmitowati \& Utami, 2017; Hodiyanto, 2017; Umar, 2012).

Kemampuan komunikasi matematika lisan meliputi berbicara, mendengarkan, berdiskusi, dan bertukar pendapat. Sedangkan kemampuan komunikasi matematis tertulis meliputi penyajian dalam bentuk grafik, tabel, simbol, persamaan dalam menyelesaikan suatu permasalahan, (Hodiyanto, 2017). Silver et al dalam (Kosko, 2010) menyatakan bahwa kemampuan komunikasi matematis tertulis dianggap lebih mampu membantu individu untuk menyampaikan gagasan matematik. (Fuehrer, 2009) juga berpendapat bahwa dengan menulis, individu dapat menjelaskan gagasannya secara lebih detail sehingga akan memaksa mereka untuk benar-benar memahami permasalahan yang dihadapi. (Pantaleon et al., 2018) menambahkan salah satu alasan pentingnya kemampuan komunikasi matematis tertulis adalah pendidik dapat mengetahui pemahaman matematika peserta didik dan dapat membuat tindak lanjut untuk membantu meningkatkan kemampuan peserta didik.

Pada penelitian ini, ditentukan lima indikator untuk mengukur kemampuan komunikasi matematis yang disaring dari beberapa pendapat (Tabel 1), yaitu: (1) menggambarkan situasi masalah; (2) menyatakan solusi masalah menggunakan gambar, bagan, tabel atau penyajian secara aljabar; (3) menginterpretasikan ide atau gagasan dalam bentuk tulisan; (4) menggunakan bahasa matematika dan simbol secara tepat; (5) merepresentasikan konsep matematika dan solusinya. 
Tabel 1. Indikator Kemampuan Komunikasi Matematis

\begin{tabular}{|c|c|c|}
\hline (Purnama \& Afriansyah, 2016) & (Disasmitowati \& Utami, 2017) & $\begin{array}{c}\text { Sumarno (Dilla et al., 2018; Paridjo \& } \\
\text { Waluya, 2017) }\end{array}$ \\
\hline $\begin{array}{l}\text { 1. menjelaskan ide, situasi dan relasi } \\
\text { matematis dengan benda nyata, } \\
\text { gambar, grafik dan aljabar } \\
\text { 2. menghubungkan benda nyata, } \\
\text { gambar atau diagram ke dalam } \\
\text { ide matematika } \\
\text { 3. menyatakan peristiwa sehari-hari } \\
\text { dalam bahasa atau simbol } \\
\text { matematika }\end{array}$ & $\begin{array}{l}\text { 1. mengekspresikan ide } \\
\text { matematika } \\
\text { 2. memahami, menafsirkan, dan } \\
\text { menilai atau merespon ide-ide } \\
\text { matematika } \\
\text { 3. menggunakan istilah, notasi dan } \\
\text { simbol untuk } \\
\text { mempresentasikan ide } \\
\text { matematika }\end{array}$ & $\begin{array}{l}\text { 1. menghubungkan objek nyata, gambar } \\
\text { dan diagram ke dalam gagasan } \\
\text { matematika } \\
\text { 2. menjelaskan ide situasi dan hubungan } \\
\text { matematika dengan benda nyata, } \\
\text { gambar, grafik dan aljabar } \\
\text { 3. menyatakan kejadian sehari-hari } \\
\text { dalam bahasa atau simbol matematika } \\
\text { 4. membaca, mendengarkan, berdiskusi, } \\
\text { dan menulis tentang matematika } \\
\text { 5. membuat hipotesis, argumen, } \\
\text { merumuskan definisi dan generalisasi } \\
\text { 6. merepresentasikan konsep } \\
\text { matematika yang dipelajari dan } \\
\text { solusinya }\end{array}$ \\
\hline
\end{tabular}

\section{METODE}

Jenis penelitian ini adalah penelitian kualitatif karena ditujukan untuk menganalisis lebih mendalam mengenai kemampuan komunikasi matematis mahasiswa. Selain itu, dalam penelitian ini hipotesis tidak dinyatakan sebelumnya dan tidak dilakukan analisis data dengan menghubungkan satu variabel dengan variabel yang lain untuk menarik kesimpulan. Penelitian dilakukan dengan grounded theory yaitu teori yang dikembangkan secara induktif dan melalui interaksi secara simultan dengan data di lapangan (Alwasilah, 2011). Jadi tidak menghasilkan teori baru berdasarkan teori yang sudah ada, melainkan menemukan teori baru berdasarkan data empirik.

Subyek dalam penelitian ini adalah mahasiswa semester VI.A dan VI.B Program Studi Pendidikan Matematika FKIP Universitas Veteran Bangun Nusantara Sukoharjo Tahun Akademik 2016/2017. Sampling dilakukan dengan teknik purposive sampling yaitu teknik pengambilan sampel sumber data dengan pertimbangan tertentu, (Sugiyono, 2008). Pertimbangan yang dimaksud dalam penelitian ini adalah pengambilan sampel berdasarkan tiga kategori yaitu mahasiswa yang memiliki tingkat komunikasi matematika tinggi, sedang, dan rendah. Pengkategorian tersebut berdasarkan pada rata-rata $(\mu)$ dan standar deviasi $(\sigma)$ skor kemampuan komunikasi matematis sesuai tabel 2.

Tabel 2. Tingkat kemampuan komunikasi matematis mahasiswa

$\begin{array}{cc}\text { Kemampuan Komunikasi Matematis } & \text { Kategori } \\ \text { skor } \geq \mu+\frac{1}{2} \sigma & \text { tinggi } \\ \mu-\frac{1}{2} \sigma<\text { skor }<\mu+\frac{1}{2} \sigma & \text { sedang } \\ \text { skor } \leq \mu-\frac{1}{2} \sigma & \text { rendah }\end{array}$


Data dalam penelitian ini bersifat naratif dan uraian. Jenis data dibagi menjadi 2 yaitu: (1) data tertulis yang diperoleh berdasarkan tes kemampuan komunikasi matematis pada pembelajaran relasi rekurensi; (2) data lisan yang diperoleh dari hasil wawancara dengan tiga mahasiswa yang diambil secara random dari tiap kategori tingkat kemampuan komunikasi matematis tinggi, sedang, dan rendah. Sebelum tes kemampuan komunikasi matematis dan pedoman wawancara digunakan sebagai instrumen bantu penelitian, maka dilakukan penilaian oleh ahli untuk validasi instrumen terlebih dahulu dengan aspek penilaian pada tabel 3.

Tabel 3. Aspek Penilaian Instrumen Bantu

\begin{tabular}{|c|c|c|}
\hline Instrumen Bantu & Aspek Penilaian & Indikator Penilaian \\
\hline \multirow{12}{*}{$\begin{array}{l}\text { Tes kemampuan } \\
\text { komunikasi } \\
\text { matematika }\end{array}$} & \multirow[t]{6}{*}{ 1. Materi } & 1. kesesuaian dengan kisi-kisi \\
\hline & & 2. kesesuaian dengan tujuan pembelajaran dan KD \\
\hline & & 3. menjabarkan indikator sesuai KD \\
\hline & & 4. kesesuaian dengan materi tes \\
\hline & & $\begin{array}{l}\text { 5. memuat seluruh aspek penilaian kemampuan } \\
\text { komunikasi matematis }\end{array}$ \\
\hline & & $\begin{array}{l}\text { 6. kemampuan tes mengukur kemampuan } \\
\text { komunikasi matematis }\end{array}$ \\
\hline & \multirow[t]{3}{*}{ 2. Konstruksi kalimat } & 7. kesesuaian bahasa dengan EYD \\
\hline & & $\begin{array}{l}\text { 8. penggunaan bahasa yang mudah dipahami dan } \\
\text { sesuai dengan tingkat perkembangan kognisi } \\
\text { mahasiswa }\end{array}$ \\
\hline & & 9. penggunaan bahasa yang tidak ambigu \\
\hline & \multirow[t]{3}{*}{ 3. Kesesuian bahasa } & $\begin{array}{l}\text { 10. konstruksi soal yang tisak tergantung satu } \\
\text { sama lain }\end{array}$ \\
\hline & & 11. penulisan petunjuk soal \\
\hline & & $\begin{array}{l}\text { 12. permasalahan yang disusun mengarah pada } \\
\text { kesimpulan }\end{array}$ \\
\hline \multirow{8}{*}{$\begin{array}{c}\text { Pedoman } \\
\text { wawancara }\end{array}$} & \multirow{3}{*}{$\begin{array}{l}\text { 1. Kesesuaian isi dengan } \\
\text { tujuan wawancara }\end{array}$} & 1. kesesuaian dengan kisi-kisi \\
\hline & & $\begin{array}{l}\text { 2. memuat seluruh aspek penilaian kemampuan } \\
\text { komunikasi matematis }\end{array}$ \\
\hline & & $\begin{array}{l}\text { 3. kemampuan instrumen memberikan informasi } \\
\text { lebih dalam mengukur kemampuan komunikasi } \\
\text { matematis }\end{array}$ \\
\hline & \multirow{2}{*}{$\begin{array}{l}\text { 2. Kejelasan petunjuk } \\
\text { wawancara dan pertanyaan } \\
\text { yang disampaikan }\end{array}$} & 4. penggunaan bahasa yang baik dan komunikatif \\
\hline & & $\begin{array}{l}\text { 5. penggunaan bahasa yang sesuai dengan tingkat } \\
\text { perkembangan kognisi mahasiswa } \\
\text { 6. penggunaan bahasa yang tidak ambigu }\end{array}$ \\
\hline & \multirow{3}{*}{ 3. Kesesuaian bahasa } & 7. adanya petunjuk dalam pelaksanaan wawancara \\
\hline & & 8. butir pertanyaan disusun secara sistematis \\
\hline & & 9. butir pertanyaan mengarah pada kesimpulan \\
\hline
\end{tabular}

Analisis data meliputi reduksi data, penyajian data, dan verifikasi data. Proses analisis data dilakukan dengan prosedur sebagai berikut:

1. Analisis data tertulis, dilakukan terhadap jawaban mahasiswa menjawab tes materi relasi rekurensi. Melalui jawaban tersebut diukur tingkat kemampuan komunikasi matematis mahasiswa berdasarkan indikator yang telah ditetapkan. Selanjutnya mahasiswa dikategorikan menjadi 3 kategori berdasarkan tingkat kemampuan komunikasi matematis seperti pada tabel 3.

2. Analisis data hasil wawancara, diawali dengan reduksi data yaitu dengan merangkum, memilih data yang penting, menyederhanakan data sesuai dengan fokus penelitian, dan transformasi data mentah yang berasal dari catatan tertulis di lapangan. Selanjutnya data disajikan dalam bentuk transkrip wawancara dan ditarik kesimpulan dari data yang telah dikumpulkan dan memverikasi kesimpulan tersebut. Kesimpulan 
yang dikemukakan masih bersifat sementara dan akan berubah bila tidak ada bukti kuat yang mendukung pada tahap pengumpulan data berikutnya. Wawancara dilakukan terhadap satu mahasiswa dari tiap kategori yang dipilih secara purposive sampling. Pertimbangan dalam penentuan subyek adalah subyek yang paling banyak melakukan kesalahan pada tiap kriteria kemampuan komunikasi matematis.

\section{HASIL DAN PEMBAHASAN}

Hasil pengembangan instrumen bantu pertama yang berupa tes tertulis terdiri dari tiga soal uraian relasi rekurensi. Soal pertama mengenai penentuan relasi rekurensi dari suatu permasalahan, soal kedua tentang penyelesaian relasi rekurensi dengan metode iterasi, dan soal ketiga mengenai penyelesaian relasi rekurensi homogen linier dengan persamaan karakteristik. Secara umum, hasil validasi dari kedua validator adalah instrumen layak digunakan dengan sedikit perbaikan pada bahasa dan petunjuk mengerjakan soal. Sedangkan hasil pengembangan instrumen kedua yang berupa pedoman wawancara dinilai layak untuk mengukur kemampuan komunikasi matematis mahasiswa dengan sedikit saran dari validator I mengenai penggunaan bahasa dan revisi untuk butir pertanyaan nomor 3 .

Tabel 4 menyajikan banyak mahasiswa dengan tingkat kemampuan komunikasi matematis tinggi, sedang, dan rendah yang ditentukan berdasarkan tabel 3. Selanjutnya ditentukan 3 subyek dari masing-masing kategori untuk dianalisis hasil tes dan dilakukan wawancara untuk mendeksripsikan kemampuan komunikasi matematis pada tiap kategori. Untuk dapat menganalisis kemampuan komunikasi matematis mahasiswa secara lebih mendalam maka pemilihan dilakukan atas dasar subyek yang melakukan kesalahan terbanyak pada setiap kategori. Dari kesalahan-kesalahan yang dilakukan mahasiswa tersebut, informasi lebih mendalam mengenai kemampuan komunikasi matematis mahasiswa dan hal-hal yang menghambat perkembangan kemampuan komunikasi matematis mahasiswa dapat diketahui.

Tabel 4. Banyak Mahasiswa Berdasarkan Tingkat Kemampuan Komunikasi Matematis

\begin{tabular}{ccccc}
\hline \multirow{2}{*}{ Kelas } & \multicolumn{3}{c}{$\begin{array}{c}\text { Banyak subyek dengan } \\
\text { tingkat KM }\end{array}$} & $\begin{array}{c}\text { Banyak } \\
\end{array}$ \\
\cline { 2 - 4 } & Tinggi & Sedang & Rendah & \\
\hline VI.A & 9 & 4 & 11 & 24 \\
VI.B & 11 & 12 & 5 & 28 \\
\hline Jumlah & 20 & 16 & 16 & 52 \\
\hline
\end{tabular}

Tabel 5. Hasil Penentuan Subyek Penelitian

\begin{tabular}{ccc}
\hline No & Subyek & $\begin{array}{c}\text { Tingkat Kemampuan } \\
\text { Komunikasi Matematis }\end{array}$ \\
\hline 1 & ND & Tinggi \\
2 & EH & Sedang \\
3 & MS & Rendah \\
\hline
\end{tabular}


Berdasarkan hasil analisis terhadap 52 jawaban mahasiswa dapat dirangkum persentase banyaknya mahasiswa yang mampu memenuhi masing-masing indikator tersebut pada tabel 6.

Tabel 6. Persentase Banyaknya Mahasiswa yang Memenuhi Tiap Indikator Kemampuan Komunikasi Matematis

\begin{tabular}{lcc}
\hline \multicolumn{1}{c}{ Indikator } & $\begin{array}{c}\text { Banyak } \\
\text { mahasiswa yang } \\
\text { memenuhi }\end{array}$ & Persentase \\
\hline $\begin{array}{l}\text { Menggambarkan situasi masalah } \\
\begin{array}{l}\text { Menyatakan solusi masalah menggunakan } \\
\text { gambar, bagan, tabel, atau penyajian secara }\end{array}\end{array}$ & 45 & $86,54 \%$ \\
$\begin{array}{l}\text { aljabar } \\
\text { Menginterpretasikan ide atau gagasan dalam }\end{array}$ & 32 & $61,54 \%$ \\
$\begin{array}{l}\text { bentuk tulisan } \\
\text { Menggunakan bahasa matematika dan simbol }\end{array}$ & 25 & $48,07 \%$ \\
$\begin{array}{l}\text { secara tepat } \\
\text { Merepresentasikan konsep matematika dan } \\
\text { solusinya }\end{array}$ & 42 & $80,77 \%$ \\
\hline
\end{tabular}

Persentase capaian kemampuan komunikasi matematis tertinggi ada pada menggambarkan situasi masalah yaitu sebesar $86,54 \%$ (tabel 6). Ini berarti, berdasarkan analisis terhadap 52 jawaban tes kemampuan komunikasi matematis, sebesar $86,54 \%$ atau sebanyak 45 mahasiswa mampu menggambarkan situasi masalah. Sedangkan persentase capaian kemampuan komunikasi matematis terendah ada pada aspek menginterpretasikan ide atau gagasan dalam bentuk tulisan yaitu se.

Untuk mendapatkan informasi yang lebih mendalam mengenai kemampuan komunikasi matematis yang dimiliki subyek penelitian, maka dilakukan analisis terhadap jawaban dan wawancara. Berdasarkan kedua analisis ini dilakukan triangulasi metode untuk mendapatkan data valid. Tabel 7, 8 dan 9 menyajikan hasil analisis yang dilakukan terhadap subyek ND, EH, dan MS.

Tabel 7. Hasil analisis subyek ND (Kategori Tinggi)

\begin{tabular}{|c|c|c|}
\hline Indikator & Analisis Jawaban & Analisis wawancara \\
\hline $\begin{array}{l}\text { Menggambarkan situasi } \\
\text { masalah }\end{array}$ & $\begin{array}{l}\text { Subyek ND menggambarkan permasalahan } \\
\text { dengan jelas dan tepat. Subyek ND } \\
\text { menggambarkan apa yang diketahui dan } \\
\text { ditanyakan dengan tepat }\end{array}$ & $\begin{array}{l}\text { Subyek ND } \text { menggambarkan } \\
\text { permasalahan dengan jelas dan tepat. } \\
\text { Subyek ND menggambarkan apa yang } \\
\text { diketahui dan ditanyakan dengan tepat }\end{array}$ \\
\hline $\begin{array}{l}\text { Menyatakan solusi masalah } \\
\text { menggunakan gambar, } \\
\text { bagan, tabel, atau } \\
\text { penyajian secara aljabar }\end{array}$ & $\begin{array}{l}\text { Subyek ND mampu menyatakan solusi } \\
\text { masalah menggunakan tabel untuk } \\
\text { mendapatkan pola dari perkembangbiakan } \\
\text { hamster yang pada akhirnya dapat } \\
\text { menentukan bentuk relasi rekurensi. }\end{array}$ & $\begin{array}{l}\text { Subyek ND lebih mudah menyatakan } \\
\text { solusi masalah menggunakan tabel untuk } \\
\text { mendapatkan pola dari } \\
\text { perkembangbiakan hamster }\end{array}$ \\
\hline $\begin{array}{l}\text { Menginterpretasikan ide } \\
\text { atau gagasan dalam bentuk } \\
\text { tulisan }\end{array}$ & $\begin{array}{l}\text { Subyek ND mampu menginterpretasikan } \\
\text { ide atau gagasan dalam bentuk tulisan, } \\
\text { menuliskan idenya secara jelas dengan } \\
\text { menjawab pertanyaan-pertanyaan yang } \\
\text { diberikan. }\end{array}$ & $\begin{array}{l}\text { Subyek ND merasa lebih mudah } \\
\text { menuliskan idenya sesuai dengan bahasa } \\
\text { dan pemikirannya daripada menuliskan } \\
\text { jawabannya secara langsung. }\end{array}$ \\
\hline
\end{tabular}




\begin{tabular}{lll}
\hline \multicolumn{1}{c}{ Indikator } & \multicolumn{1}{c}{ Analisis Jawaban } & \multicolumn{1}{c}{ Analisis wawancara } \\
\hline Menggunakan bahasa & Subyek ND mampu mengkomunikasikan & Subyek ND mengetahui bagaimana aturan \\
matematika dan simbol & idenya dalam menyelesaikan permasalahan & penulisan simbol relasi rekurensi secara \\
secara tepat & dengan menggunakan simbol secara tepat. & tepat dan dapat memberikan penulisan \\
& ND juga menuliskan bentuk relasi rekurensi & yang benar pada jawaban sebelumnya \\
& yang telah diperoleh dengan bahasa & \\
Merepresentasikan konsep & Subyek ND mampu merepresentasikan Subyek ND mampu merepresentasikan \\
matematika dan solusinya & konsep matematika dan solusinya dengan konsep matematika dan solusinya dengan \\
& tepat dan relevan dengan soal meskipun jelas dan tepat serta relevan dengan soal. \\
& ada sedikit kesalahan penulisan . Akan & \\
& tetapi tidak mengurangi kebenaran dari & \\
konsep relasi rekurensi. & \\
\hline
\end{tabular}

Kesimpulan hasil analisis kemampuan komunikasi matematis subyek ND:

Subyek ND mempunyai tingkat kemampuan komunikasi matematis yang tinggi. Hal ini dikarenakan dalam menyelesaikan permasalahan subyek ND mampu memenuhi seluruh indikator yang ditetapkan untuk mengukur kemampuan komunikasi matematis.

Tabel 8. Hasil analisis subyek EH (Kategori Sedang)

\begin{tabular}{|c|c|c|}
\hline Indikator & Analisis Jawaban & Analisis wawancara \\
\hline $\begin{array}{l}\text { Menggambarkan situasi } \\
\text { masalah }\end{array}$ & $\begin{array}{l}\text { Subyek EH tidak menuliskan situasi masalah } \\
\text { tetapi mengetahui apa yang diketahui dan apa } \\
\text { yang ditanyakan dari soal }\end{array}$ & $\begin{array}{l}\text { Subyek EH tidak terbiasa menuliskan } \\
\text { situasi masalah tetapi mengetahui apa } \\
\text { yang diketahui dari soal dan apa yang } \\
\text { ditanyakan dengan tepat }\end{array}$ \\
\hline $\begin{array}{l}\text { Menyatakan solusi masalah } \\
\text { menggunakan gambar, } \\
\text { bagan, tabel, atau penyajian } \\
\text { secara aljabar }\end{array}$ & $\begin{array}{l}\text { Subyek EH mampu menyatakan solusi masalah } \\
\text { menggunakan tabel tetapi tidak menjelaskan arti } \\
\text { notasi dalam tabel dan ada sedikit kesalahan } \\
\text { dalam penulisan }\end{array}$ & $\begin{array}{l}\text { Subyek EH lebih mudah menyelesaikan } \\
\text { permasalahan dengan menggunakan } \\
\text { tabel dan dapat menjelaskan kesalahan } \\
\text { tulis yang dilakukan saat menjawab soal }\end{array}$ \\
\hline $\begin{array}{l}\text { Menginterpretasikan ide } \\
\text { atau gagasan dalam bentuk } \\
\text { tulisan }\end{array}$ & $\begin{array}{l}\text { Subyek EH kurang mampu menginterpretasikan } \\
\text { ide atau gagasan dalam bentuk tulisan. Subyek } \\
\text { EH tidak memberikan penjelasan lebih lanjut } \\
\text { darimana jawabannya diperoleh }\end{array}$ & $\begin{array}{l}\text { Subyek EH tidak mampu menuliskan } \\
\text { idenya dalam bentuk tulisan. Subyek EH } \\
\text { terbiasa menuliskan langsung } \\
\text { jawabannya tanpa menjelaskan } \\
\text { darimana jawaban tersebut diperoleh }\end{array}$ \\
\hline $\begin{array}{l}\text { Menggunakan bahasa } \\
\text { matematika dan simbol } \\
\text { secara tepat }\end{array}$ & $\begin{array}{l}\text { Subyek EH mampu mengkomunikasikan idenya } \\
\text { dalam menyelesaikan permasalahan dengan } \\
\text { menggunakan simbol meskipun kurang lengkap. } \\
\text { EH juga menuliskan bentuk relasi rekurensi yang } \\
\text { telah diperoleh dengan bahasa matematika yang } \\
\text { berbeda tetapi tidak relevan dengan soal. }\end{array}$ & $\begin{array}{l}\text { Subyek EH mampu menggunakan simbol } \\
\text { dengan baik. Akan tetapi penggunaan } \\
\text { bahasa matematika kurang baik. }\end{array}$ \\
\hline $\begin{array}{l}\text { Merepresentasikan konsep } \\
\text { matematika dan solusinya }\end{array}$ & $\begin{array}{l}\text { Subyek EH mampu merepresentasikan konsep } \\
\text { matematika dan solusinya dengan tepat dan } \\
\text { relevan dengan soal meskipun tidak dapat } \\
\text { menuliskan jawabannya dengan baik }\end{array}$ & $\begin{array}{l}\text { Subyek EH mampu merepresentasikan } \\
\text { konsep matematika dan solusinya } \\
\text { dengan tepat meskipun kurang baik } \\
\text { dalam penulisannya }\end{array}$ \\
\hline
\end{tabular}

Subyek EH mempunyai tingkat kemampuan komunikasi matematis yang sedang. Hal ini dikarenakan dalam menyelesaikan permasalahan subyek EH tidak dapat menggambarkan situasi masalah dan menginterpretasikan ide atau gagasan dalam bentuk tulisan. Selain itu, masih ada sedikit kesalahan dalam menyatakan solusi masalah menggunakan tabel. Dalam menggunakan bahasa matematika dan simbol juga masih ada sedikit kesalahan bahkan memberikan alternatif jawaban yang lain tetapi tidak relevan dengan soal. Kemampuan subyek NH dalam menuliskan jawabannya juga kurang baik. Akan tetapi, subyek EH dapat menjelaskan jawabannya dengan tepat pada saat wawancara. 
Tabel 9. Hasil analisis subyek MS (Kategori Rendah)

\begin{tabular}{|c|c|c|}
\hline Indikator & Analisis Jawaban & Analisis wawancara \\
\hline $\begin{array}{l}\text { Menggambarkan situasi } \\
\text { masalah }\end{array}$ & $\begin{array}{l}\text { Subyek MS tidak menuliskan situasi masalah } \\
\text { tetapi mengetahui apa yang diketahui dan } \\
\text { apa yang ditanyakan dari soal }\end{array}$ & $\begin{array}{l}\text { Subyek MS mengetahui apa yang diketahui dari } \\
\text { soal dan apa yang ditanyakan tetapi } \\
\text { berpendapat bahwa menuliskannya kembali } \\
\text { tidak perlu karena sudah ada di dalam soal. }\end{array}$ \\
\hline $\begin{array}{l}\text { Menyatakan solusi } \\
\text { masalah menggunakan } \\
\text { gambar, bagan, tabel, atau } \\
\text { penyajian secara aljabar }\end{array}$ & $\begin{array}{l}\text { Subyek MS tidak menggunakan gambar, } \\
\text { bagan, tabel, atau penyajian secara aljabar } \\
\text { dalam menyelesaikan permasalahan }\end{array}$ & $\begin{array}{l}\text { Subyek MS merasa kesulitan } \\
\text { mengimplemetnasikan permasalahan kedalam } \\
\text { bentuk tabel, grafik, gambar, atau penyelesaian } \\
\text { secara aljabar. }\end{array}$ \\
\hline $\begin{array}{l}\text { Menginterpretasikan ide } \\
\text { atau gagasan dalam } \\
\text { bentuk tulisan }\end{array}$ & $\begin{array}{l}\text { Subyek MS kurang mampu } \\
\text { menginterpretasikan ide atau gagasan dalam } \\
\text { bentuk tulisan. Subyek MS tidak memberikan } \\
\text { penjelasan lebih lanjut darimana jawabannya } \\
\text { diperoleh }\end{array}$ & $\begin{array}{l}\text { Subyek MS tidak mampu menuliskan idenya } \\
\text { dalam bentuk tulisan. Subyek MS terbiasa } \\
\text { menuliskan langsung jawabannya tanpa } \\
\text { menjelaskan darimana jawaban tersebut } \\
\text { diperoleh. }\end{array}$ \\
\hline $\begin{array}{l}\text { Menggunakan bahasa } \\
\text { matematika dan simbol } \\
\text { secara tepat }\end{array}$ & $\begin{array}{l}\text { Subyek MS mampu mengkomunikasikan } \\
\text { idenya dalam menyelesaikan permasalahan } \\
\text { dengan menggunakan simbol meskipun } \\
\text { kurang lengkap. }\end{array}$ & $\begin{array}{l}\text { Subyek EH mampu menggunakan simbol } \\
\text { dengan baik dan mampu menjelaskan arti dari } \\
\text { simbol yang digunakan }\end{array}$ \\
\hline $\begin{array}{l}\text { Merepresentasikan konsep } \\
\text { matematika dan solusinya }\end{array}$ & $\begin{array}{l}\text { Subyek MS tidak mampu merepresentasikan } \\
\text { konsep matematika dan solusinya. Tidak ada } \\
\text { jawaban dari subyek MS yang mengarah pada } \\
\text { bentuk eksplisit relasi rekurensi. }\end{array}$ & $\begin{array}{l}\text { Subyek MS tidak dapat mampu } \\
\text { merepresentasikan konsep matematika dan } \\
\text { solusinya karena tidak dapat mencari bentuk } \\
\text { eksplisit dari permasalahan yang diberikan } \\
\text { padahal subyek MS paham konsepnya. }\end{array}$ \\
\hline
\end{tabular}

Kesimpulan hasil analisis kemampuan komunikasi matematis subyek MS: Subyek MS mempunyai tingkat kemampuan komunikasi matematis yang rendah. Hal ini dikarenakan dalam menyelesaikan permasalahan subyek MS tidak dapat menggambarkan situasi masalah dan menginterpretasikan ide atau gagasan dalam bentuk tulisan. Selain itu, subyek MS juga tidak menyelesaikan permasalahan menggunakan gambar, bagan, tabel, maupun penyajian secara aljabar. Bahkan dalam hasil tes dari subyek MS, tidak ada jawaban yang mengarah pada bentuk eksplisit dari relasi rekurensi. Hal ini berarti tidak ada kemampuan dari subyek MS untuk merepresentasikan konsep matematika dan solusinya.

Triangulasi metode dilakukan setelah diperoleh hasil analisis kemampuan komunikasi matematis mahasiswa berdasarkan hasil tes pemahaman relasi rekurensi dan wawancara pada tabel 7, 8 dan 9. Jadi dapat disimpulkan bahwa 1). Pada subyek dengan tingkat kemampuan komunikasi matematis tinggi, semua indikator dapat terpenuhi meskipun ada sedikit kekurangan dalam menuliskan simbol. Akan tetapi, dalam pelaksanaan wawancara subyek dapat melengkapi jawabannya dengan tepat. 2). Pada subyek dengan tingkat kemampuan komunikasi matematis sedang, kesulitan ada pada menginterpretasikan gagasan dalam bentuk tulisan. Data ini valid dengan data yang diperoleh setelah wawancara yaitu subyek mempunyai ide mengenai relasi rekurensi tetapi sulit menjelaskannya dalam bentuk tulisan. 3). Pada subyek dengan tingkat kemampuan komunikasi matematis rendah, berdasarkan analisis terhadap hasil tes, subyek hanya mampu mencapai indikator menggunakan simbol. Akan tetapi, dari hasil wawancara, diketahui bahwa subyek dapat menggunakan simbol lain untuk menuliskan bentuk dari relasi rekuensi. 


\section{SIMPULAN}

Berdasarkan hasil analisis data dan pembahasan pada bab sebelumnya, diperoleh kesimpulan bahwa Persentase kemampuan komunikasi matematis paling tinggi ada pada indikator menggambarkan situasi masalah yaitu sebanyak 45 atau sebesar 86,54\% dari 52 mahasiswa mampu menggambarkan situasi masalah. Sedangkan persentase capaian kemampuan komunikasi matematis terendah adalah pada indikator mampu menginterpretasikan ide atau gagasan dalam bentuk tulisan karena hanya 25 mahasiswa atau $48,07 \%$ mahasiswa yang mampu menginterpretasikan ide atau gagasan dalam bentuk tulisan.

Pada mahasiswa dengan tingkat kemampuan komunikasi tinggi, tidak ada kesulitan dalam pembelajaran relasi rekurensi. Pada mahasiswa dengan tingkat kemampuan komunikasi matematis sedang, kesulitan ada pada menginterpretasikan gagasan dalam bentuk tulisan. Sedangkan mahasiswa dengan tingkat komunikasi matematis rendah hanya mampu menggunakan bahasa matematika dan simbol secara tepat.

\section{DAFTAR PUSTAKA}

Alwasilah, C. (2011). Pokoknya Kualitatif. Jakarta: Pustaka Jaya.

Dilla, R. S., Adriati, N., \& Novtiar, C. (2018). Analisis Komunikasi Matematis Siswa SMP Pada Materi Segi Empat. Jurnal Math Educator Nusantara: Wahana Publikasi Karya Tulis Ilmiah Di Bidang Pendidikan Matematika, 4(1), 57-62. https://doi.org/10.29407/nor.v5i1.12095

Disasmitowati, C. E., \& Utami, A. S. (2017). Analysis of Students' Mathematical Communication Skill for Algebraic Factorization Using Algebra Block. Proceedings The 2017 International Conference on Research in Education - Sanata Dharma University, 72-84.

Fuehrer, S. (2009). Writing in Math Classs? Written Communication in Mathematics Classroom. University of Nebraska.

Hodiyanto. (2017). Kemampuan Komunikasi Matematis Dalam Pembelajaran Matematika. AdMathEdu, 7(1), 9-18.

Husna, R., Saragih, S., dan S. (2013). Peningkatan Kemampuan Pemecahan Masalah dan Komunikasi Matematik Melalui Pendekatan Matematika Realistik Pada Siswa SMP Kelas VII Langsa. Jurnal Pendidikan Matematika PARADIKMA, 6(2), 175-186.

Jatmiko, J., \& Yohanie, D. D. (2018). Diskripsi kemampuan komunikasi matematis siswa pondok. JIPMat (Jurnal Ilmiah Pendidikan Matematika), 3(2), 86-91. https://doi.org/http://dx.doi.org/10.26877/jipmat.v3i2.2743

Jazuli, A. (2009, December). Berpikir Kreatif dalam Kemampuan Komunikasi Matematika. In Prosiding Seminar Nasional Matematika dan Pendidikan Matematika Jurusan Pendidikan Matematika FMIPA UNY (Vol. 2, pp. 209-220). 
Khan, A., Khan, S., Zia, S., \& Khan, M. (2017). Communication Skills of a Teacher and Its Role in the Development of the Students' Academic Success. Journal of Education and Practice, 8(1), 18-21.

Kosko, K. W. and J. L. M. W. (2010). Mathematical Communication and its Relation to the Frequency of Manipulative Use. International Electronic Journal of Mathematics Education, 5(2), 79-90.

Majid, A. (2012). Belajar dan Pembelajaran. Bandung: PT. Remaja Rosdakarya.

Murdiyanto, T., \& Mahatama, Y. (2014). Pengembangan Alat Peraga Matematika Untuk Meningkatkan Minat Dan Motivasi Belajar Matematika Siswa Sekolah Dasar. Sarwahita, 11(1), 38. https://doi.org/10.21009/sarwahita.111.07

NCTM (National Council of Teachers of Mathematics). (2000). Principles and Standards for School Mathematics. K12 Academics.

Pantaleon, K. V., Juniati, D., \& Lukito, A. (2018). The Written Mathematical Communication Profile of Prospective Math Teacher in Mathematical Proving. Journal of Physics: Conference Series, 1108(1), 0-6. https://doi.org/10.1088/1742-6596/1108/1/012008

Paridjo, P., \& Waluya, S. B. (2017). Analysis Mathematical Communication Skills Students In The Matter Algebra Based Nctm. IOSR Journal of Mathematics, 13(01), 60-66. https://doi.org/10.9790/5728-1301056066

Purnama, I. L., \& Afriansyah, E. A. (2016). Kemampuan Komunikasi Matematis Siswa Ditinjau Melalui Model Pembelajaran Kooperatif Tipe Complete Sentence dan Team Quiz. Jurnal Pendidikan Matematika, 10(1), 27-43.

Qohar, A. (2011). Mathematical Communication: What And How To Develop It In Mathematics Learning? International Seminar and the Fourth National Conference on Mathematics Education, ISBN 978-9, 978-979.

Sugiyono. (2008). Metode Penelitian Kualitatif. Bandung: Alfabeta.

Sür, B., \& Delice, A. (2016). The examination of teacher student communication process in the classroom: mathematical communication process model. SHS Web of Conferences, 26, 1-7. https://doi.org/10.1051/shsconf/20162601059

Umar, W. (2012). Membangun Kemampuan Komunikasi Matematis Siswa Dalam Pembelajaran Matematika. Jurnal IImiah Program Studi Matematika STKIP Siliwangi Bandung, 1(1).

Walle, J. A. Van de. (2006). Matematika Sekolah Dasar Dan Menegah. Jakarta: Erlangga.

Wood, L. (2012). Practice and Conceptions: Communicating Mathematics in The Workplace. Educational Studies In Mathematics, 79(1), 109-125. 